Khattab : Role Of Clays Addition On The Stability Of Collapsible Soil

\title{
Role Of Clays Addition On The Stability Of Collapsible Soil Selected From Mosul City
}

\author{
Dr. Suhail A. A. Khattab \\ Assistant Professor \\ Dr.Salah W. I. Bahhe \\ Assistant Professor \\ Khawla A. K. AL-Juari \\ Assistant Lecturer \\ University of Mosul - College of Engineering
}

\begin{abstract}
Volume changes of a collapsible soil selected from Hawy Al-Kanissa in Mosul city were studied. The Influence of addition of $(5,15$ and 30$) \%$ of low (CL) and highly plastic $(\mathrm{CH})$ clayey soil were studied. Many variables as: the initial dry unit weight, water content and applied stresses on volume change were considered. State diagrams representing gradual volume change due to these variables were also presented and discussed.

The main results were showed that the collapse potential $(\mathrm{Cp})$ increased continuously for samples mixed with (CL) soil while there were a maximum value at $(5 \%)$ of $(\mathrm{CH})$ soil. At low unit weight, $(\mathrm{Cp})$ for samples mixed with $(\mathrm{CL})$ reached a highest value at certain stress, then started to decrease, while it increased continuously using $(\mathrm{CH})$. $(\mathrm{Cp})$ of soils containing $(\mathrm{CH})$ was found to be less than that mixed with (CL) soil. Concerning soil volumetric changes using state diagrams presentation, volume change for undisturbed natural soil at low moisture content was found less than that in disturbed samples, but the inverse was obtained at saturation. Besides that, volume changes increased with the increase of the clay additive in different manner for $(\mathrm{CL})$ and $(\mathrm{CH})$ soils.
\end{abstract}

Keywords: Clay, Collapsible soil, Volume change, unsaturated soil.

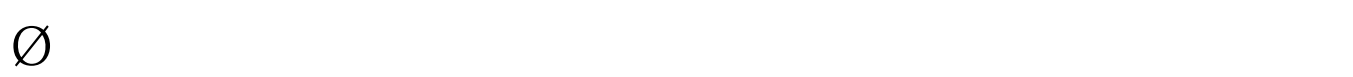

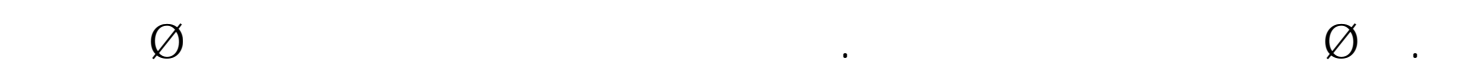 rứtding \\ rŮt ŤKE}

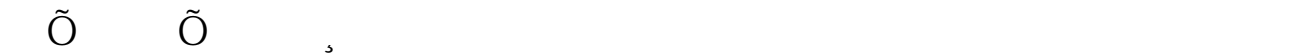
ř»

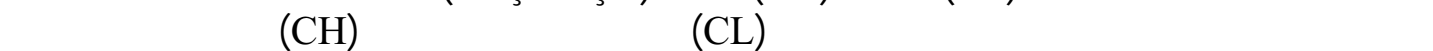
¿Ü ŚŜ ř

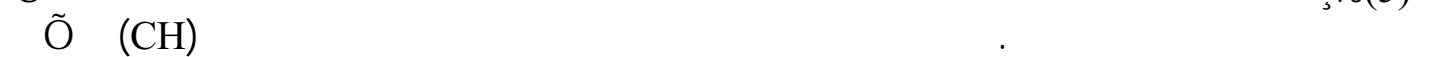

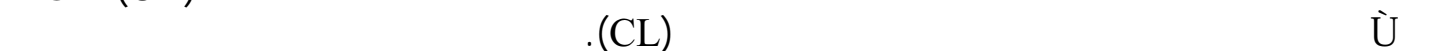

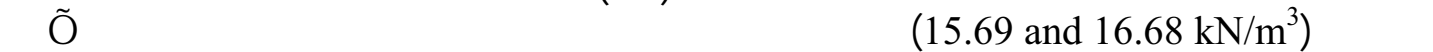

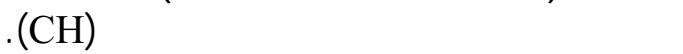

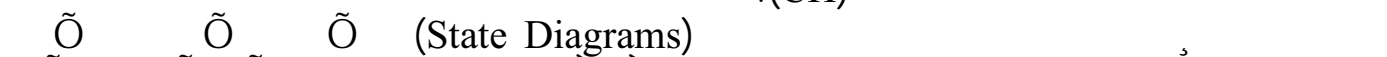

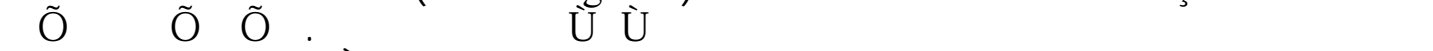

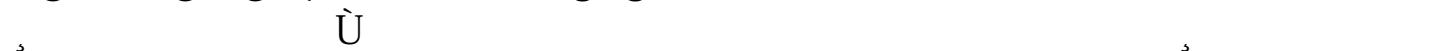

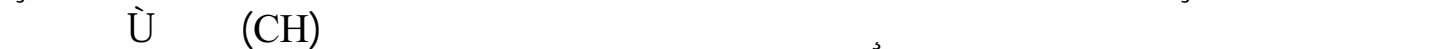

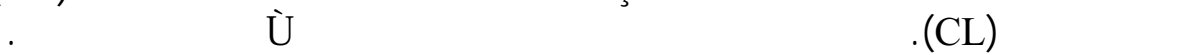

Received 2 Feb. 2006

Accepted 22 Nov. 2006 


$\begin{array}{llll}\text { Al-Rafidain Engineering } & \text { Vol.15 } & \text { No.4 } & 2007\end{array}$

\section{1-Introduction}

Volume change is as one of the major problems that should be considered by foundation engineers, especially in arid and semi arid regions. Volume change causes economic losses due to the damage occurs in buildings, bridges, highways, earth embankments and many other structures.

In the field of geotechnical engineering, it is well known that several soil problems are caused by the environmental change such as surplus of water in the soil. These geotechnical problems could be caused or generated a loss in shear strength and/or excessive deformation that includes either an increase (expansion) or decrease (settlement) in the thickness or volume of the soil. Soil suction, clay particles and some chemicals act as binder materials for coarse grain soil. When matric suction decreases, bonding agents weaken or even vanish, thus causing volumetric change and shear failure [16], [18].

The prediction of the behavior of the soil under structure is an important part of any design problem to ensure the safety of this structure. All types of compacted soils suffer from settlement that is relating to a soil type and properties. However, under certain conditions and for specific types of soils, subsequent wetting may cause additional settlement. This type of settlement is termed collapse. Clemence and Finbarr (1981) [7] defined collapsible soils as any unsaturated soil that goes through a radical rearrangement of particles and great loss of volume upon wetting with or without additional loading.

According to Dudley (1970) [9], Barden et al (1973) [5] and Mitchell (1976) [15], four factors are needed to produce the collapse in soil structure:

1. An open, partially unstable, unsaturated fabric.

2. A high enough net total stress that will cause the structure to be metastable.

3. A bonding or cementing agent that stabilizes the soil in the unsaturated condition.

4. The addition of water to the soil, which causes the bonding or cementing agent to be reduced and the interaggregate or intergranular contacts to fail in shear, resulting in a reduction in total volume of the soil mass.

The collapsible behavior of compacted and cohesive soils depends on the percentage of fines (especially clay fraction), the initial water content, the initial dry density and the energy as well as the process used in compaction [2], [3], [5], [8], [13], [14].

There are three main types of collapsible soil: collapsible loess, collapsible alluvial soils (usually high in silt content) and collapsible manmade fills.

The state diagrams consider a simple and clear method for measuring the volume change when the moisture change from dry to saturate condition especially for soil which is sensitive to change in moisture such as collapsible and expansive soil. The most important advantage for using this method is its ability to better understanding to measure the volume change under the following criteria:

1. When water content change and the applied stress remain constant. 
Khattab : Role Of Clays Addition On The Stability Of Collapsible Soil

2. When water content remains constant and the applied stress change.

3 . When water content and applied stresses are changing together.

The state diagrams recommended by Andri silvan et al (1981) [17] showed different ways to represent these diagrams. Then Al-khashab and Bahhe (1999) [3] studied the effect of particle finesse on these diagrams, then Khattab (2004) [2] used these diagrams to represent different state of compaction for soil.

This investigation was performed on collapsible alluvial soils selected from Hawy Al-Kanissa destrict, which are the most commonly occurring in Mosul city.

The main objective of this paper is to experimentally define the effect of the addition of different types and amounts of natural clayey soils to collapsible soil on their collapse potential under the same identical condition; as well as, the effect of applied load and degree of saturation on volume change of the same types of prepared soil, using the "State Diagrams".

\section{2-Laboratory Work and Test Procedure}

Disturbed and undisturbed soil samples were obtained at depth $(1.0 \mathrm{~m})$ from Hawy Al-Kanissa, located at the right bank of Tigris river in Mosul city. Undisturbed samples were taken directly by pushing the consolidation rings perpendicular on the top of perfectly leveled natural soil. They were placed on small glass plate to prevent disturbance, sealed and kept in a desiccator to insure that there is no loss in their natural water contents. The standard and modified compaction tests indicated that Hawy Al-Kanissa soil has a maximum dry unit weight of (16.48 and 17.81) $\mathrm{kN} / \mathrm{m}^{3}$ respectively as shown in Fig. (1).

Two types of soil were obtained from Al-Gara / Al-Anbar governorate and Hay Al-Shohadaa/ Mosul city at depth $(1.0 \mathrm{~m})$ and used as clay additive to Hawy AlKanissa soil with different amounts under the same identical condition. The engineering properties for all natural soils were listed in Table (1). Hawy Al-Kanissa soil characterized by low dry unit weight $\left(12.75 \mathrm{kN} / \mathrm{m}^{3}\right)$ with high initial void ratio $\left(\mathbf{e}_{\mathbf{o}}=1.054\right)$, as well as, the soil is non plastic with low liquid limit $\left(\mathbf{w}_{\mathbf{L}}=\mathbf{2 4 \%}\right)$. Therefore, Hawy Al-Kanissa soil classified as a collapsible soil according to [9], [10]. The properties of the clayey soils were shown in Table (1) and Fig. (2). The soils constituents, listed in Table (1), showed that the major clay minerals were smectite, kaolinite and mixed layers from illite and smectite respectively.

\section{Methodology:}

For the purpose of this research, the laboratory tests for the following studies were conducted:

2-1 Comparison study of collapse potential "Cp" of soil, with different types and amounts of clay soils under the same identical condition: conventional collapse tests were conducted on natural undisturbed as well as artificially prepared soil samples under different dry unit weights and applied stresses. 


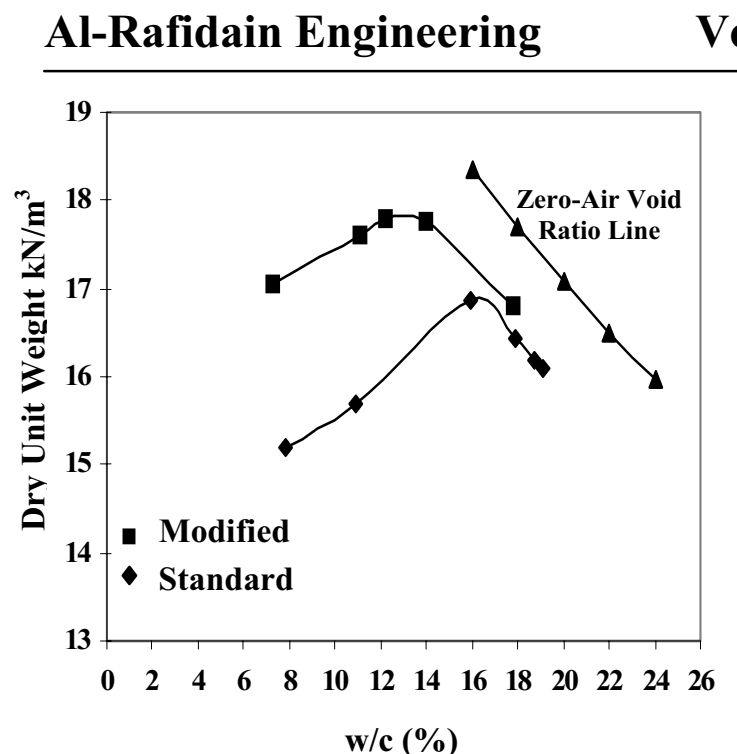

Fig. (1) Compaction Curve for Collapsible Soil $\begin{array}{lll}\text { Vol.15 } & \text { No.4 } & 2007\end{array}$

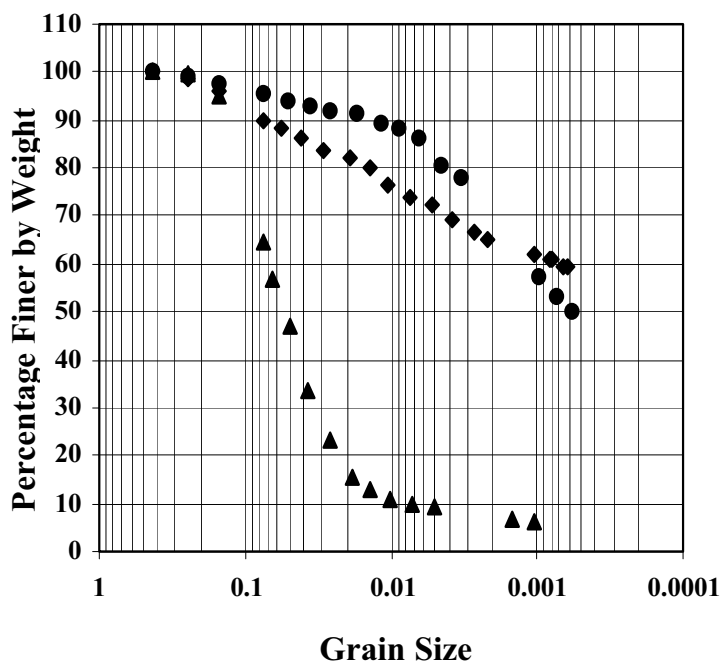

Fig. (2) Grain Size Analysis for Natural Soils

Table (1) Engineering Properties of Natural Soils.

\begin{tabular}{|c|c|c|c|}
\hline \multirow[t]{2}{*}{ Type of Test } & \multicolumn{3}{|c|}{ Type of Soil } \\
\hline & $\begin{array}{c}\text { Hawy Al- } \\
\text { Kanissa Soil }\end{array}$ & Al-Gara Soil & $\begin{array}{c}\text { Al-Shohadaa } \\
\text { Soil }\end{array}$ \\
\hline Specific Gravity & 2.67 & 2.65 & 2.72 \\
\hline $\begin{array}{c}\text { Liquid Limit \% } \\
\text { Plastic Limit \% } \\
\text { Plasticity Index \% }\end{array}$ & $\begin{array}{l}24 \\
\text { NP } \\
-\end{array}$ & $\begin{array}{l}45 \\
28 \\
17\end{array}$ & $\begin{array}{c}101 \\
50 \\
51\end{array}$ \\
\hline Sand $\%$ & 43 & 5 & 10 \\
\hline Silt\% & 49 & 26 & 25 \\
\hline Clay\% & 8 & 69 & 65 \\
\hline Classification of Soil & ML & $\mathbf{C L}$ & $\mathbf{C H}$ \\
\hline Activity of Clay & - & 0.246 & 0.785 \\
\hline Linear Shrinkage\% & 0.55 & 8.35 & 20.34 \\
\hline Total Soluble Salt\% & 4.5 & 2.05 & 1.25 \\
\hline Organic Mater\% & 1.76 & $\mathbf{0 . 8 8 7}$ & 1.834 \\
\hline *Clay Minerals & $\begin{array}{c}\text { Smectite, Illite, } \\
\text { Kaolinite, } \\
\text { Palygroskite }\end{array}$ & $\begin{array}{c}\text { Kaolinite, Illite+ } \\
\text { Smectite, } \\
\text { Palygroskite }\end{array}$ & $\begin{array}{c}\text { Illite+ Smectite, } \\
\text { Kaolinite }\end{array}$ \\
\hline *Non Clay Minerals & $\begin{array}{l}\text { Quartz, } \\
\text { Dolomite }\end{array}$ & Quartz & Quartz, Calcite \\
\hline pH & 7.95 & 7.99 & 8.19 \\
\hline $\begin{array}{c}\text { Natural Dry Unit } \\
\text { Weight }\left(\mathbf{k N} / \mathbf{m}^{3}\right)\end{array}$ & 12.750 & - & 15.206 \\
\hline
\end{tabular}

*Found by X-Ray diffraction (XRD) analysis 
Khattab : Role Of Clays Addition On The Stability Of Collapsible Soil

2-1-1 Tested samples preparation: the artificially soil samples were prepared by mixing disturbed samples with $(0,5,15,30) \%$ of two types of clayey soil to obtain mixtures with final clay content $(8,12,18,25) \%$ respectively. The static compaction method was applied to prepare sets of identical samples with the required dry unit weight. Specimens were compacted to in-situ dry unit weight $\left(12.75 \mathrm{kN} / \mathrm{m}^{3}\right)$, as well as, relative compaction of $80 \%$ of a maximum dry unit weight for modified compaction of collapsible soil $\left(14.23 \mathrm{kN} / \mathrm{m}^{3}\right)$ and $95 \%$ of standard and modified compaction $(15.69,16.68) \mathrm{kN} / \mathrm{m}^{3}$ respectively. All samples were directly compacted into consolidation ring by loading machine at a rate of $(1.25 \mathrm{~mm} / \mathrm{min})$. The prepared samples inside the ring were sealed and kept in a desiccator until conducting the tests.

2-1-2 Collapse test: two types of test were applied in conducting collapse tests for undisturbed samples, single test, according to the procedure recommended by ASTM (D 5333-92) (2003) [4], as well as the double oedometer test recommended by Jennings and knight (1957) [12]. While for compacted soil at different dry unit weights mixed with different types and amounts of clayey soil, the double oedometer test was used only.

For single test, applied loads on specimens with in-situ water content $(\mathrm{w} / \mathrm{c}=7 \%)$ with loading increment for each hour up to $(100 \mathrm{kPa})$ to represent the expected load that the collapsible soil can support. Then, water added, the deformation caused by this inundation was recorded after ( 24 hour). Then, load increments proceeded up to $(800 \mathrm{kPa})$.

For double oedometer test, two "identical" soil specimens are placed in oedometers. One specimen is tested at natural in-situ water content, which is generally quite low. The other specimen is fully saturated before the beginning of the test, stresses were applied to keep volume constant that is refer to swelling pressure for specimens, results are listed in Table (2), and then subjected to an identical compression test.

\section{2-2 Studying the volume change for collapsible soil using state diagrams:}

Undisturbed and disturbed samples with and without different percentages of clay additives were prepared in the same manner described in sec. (2-1-1). At each dry unit weight the compaction water contents are $(7,15,20) \%$ and saturated samples. For unsaturated specimen, cells were kept and sealed with Aluminum foil paper and then with several plastic bags to prevent evaporation of water during the test. Water content during the test was verified periodically through additional cells prepared for this reason. Then, conventional Oedometer tests were conducted by applying load increment $(12-800) \mathrm{kPa}$. The moisture contents under each applied load for each sample were found from identical specimen. Specific volume which represent (volume $\left(\mathrm{cm}^{3}\right)$ corresponds to $100 \mathrm{gm}$ of dry soil, $\mathrm{V}=100 / \gamma_{\mathrm{d}}$ ) was calculated under each applied load. The correlation between final water content and volume represent "State Diagram". 


$\begin{array}{llll}\text { Al-Rafidain Engineering } & \text { Vol.15 } & \text { No.4 } & 2007\end{array}$

\section{3-Results and Discussion}

\section{3-1 Effect of clay additive on the index properties of Hawy Al-Kanissa soil:}

The effect of clayey soil $(5,15,30) \%$ on the index properties of Hawy Alkanissa soil were presented in Table (3). As expected an increase in liquid limit, plastic limit, plasticity index and linear shrinkage were noted from low to high value with percentage of clay additive as shown in Table (3). The results showed a higher increase in index properties with addition of $(\mathrm{CH})$ soil than that with $(\mathrm{CL})$ soil. This could be attributed to mineralogical composition of $(\mathrm{CH})$ soil which consists of mixed layers from montmorillonit and illite which have high water adsorption ability comparing with kaoline [1].

\section{3-2 Collapse index and collapse potential for Hawy Al-Kanissa soil:}

\section{3-2-1 Undisturbed sample:}

A. Single test, typical curve of the test is plotted in Fig. (3) and collapse potential " $\mathrm{Cp}$ " is calculated as $(11.89 \%)$.

B. Double Oedometer test, typical double oedometer test is shown in Fig. (4). Two stress versus strain curves were generated, one for the partially saturated soil and the other for the saturated soil. For a given applied stress $\sigma_{n}$, the strain offset $\varepsilon$ between the two curves is called collapse strain for that stress level. Hence, collapse strain for undisturbed samples was $(10.46 \%)$ under applied pressure of $(100 \mathrm{kPa})$. The above results showed a very limited difference compared with that of single test. Same conclusion was obtained by [6], [13].

Thus, according to ASTM (D 5333-92) (2003) [4], Jennings and Knight (1975) [11] classification, Hawy Al-kanissa soil is classified as sever, sever trouble to collapse respectively.

Results from double oedometer tests showed that undisturbed samples had collapse potential $(\mathrm{Cp}=3.23 \%)$ under very light stress $(12 \mathrm{kPa})$. This indicates that the soil had the ability to collapse under its own weight only as a result of the reduction in the initial water content of the honeycombed structure of this soil.

\section{3-2-2 Disturbed sample:}

To show the effect of disturbance on collapse potential of Hawy Al-kanissa soil, samples prepared by static compaction method to an identical condition of initial dry unit weight and water content, The methods mentioned in sec. (3-2-1) were followed. Results showed that the soil had collapse potential of $(6.8,4.1) \%$ respectively under applied stress $(100 \mathrm{kPa})$

Results from single and double oedometer tests showed that the collapse potential of undisturbed samples was more than that of disturbed samples. 
Khattab : Role Of Clays Addition On The Stability Of Collapsible Soil

Table (2) Swelling Pressure (kPa) of Soils.

\begin{tabular}{|c|c|c|c|c|c|c|c|c|}
\hline \multirow{2}{*}{ Clay \% } & \multicolumn{4}{|c|}{ CL } & \multicolumn{4}{|c|}{$\mathrm{CH}$} \\
\hline & $0 \%$ & $5 \%$ & $15 \%$ & $30 \%$ & $0 \%$ & $5 \%$ & $15 \%$ & $30 \%$ \\
\hline 12.75 & * & * & * & * & * & * & * & 10.2 \\
\hline 14.23 & * & * & * & * & * & 6.8 & 25 & 50 \\
\hline 15.69 & 13.6 & 38.6 & 13.6 & 20.4 & 13.6 & 56.8 & 75 & 112.5 \\
\hline 16.68 & 25 & 38.6 & 52.2 & 52.2 & 25 & 75 & 175 & 200 \\
\hline
\end{tabular}

Table (3) Engineering Properties of Soil Mixtures

\begin{tabular}{|c|c|c|c|c|c|c|}
\hline Type of test & $\begin{array}{l}\text { Natural } \\
\text { Soil } \\
\text { Mixed } \\
\text { with 5\% } \\
\text { of } \\
\text { CL } \\
\end{array}$ & $\begin{array}{c}\text { Natural } \\
\text { Soil } \\
\text { Mixed } \\
\text { with 5\% } \\
\text { of } \\
\text { CH } \\
\end{array}$ & $\begin{array}{l}\text { Natural } \\
\text { Soil } \\
\text { Mixed } \\
\text { with } \\
15 \% \text { of } \\
\text { CL }\end{array}$ & $\begin{array}{c}\text { Natural } \\
\text { Soil } \\
\text { Mixed } \\
\text { with } \\
15 \% \text { of } \\
\text { CH }\end{array}$ & $\begin{array}{l}\text { Natural } \\
\text { Soil } \\
\text { Mixed } \\
\text { with } \\
30 \% \text { of } \\
\text { CL }\end{array}$ & $\begin{array}{c}\text { Natural } \\
\text { Soil } \\
\text { Mixed } \\
\text { with } \\
30 \% \text { of } \\
\text { CH } \\
\end{array}$ \\
\hline Specific Gravity(Gs) & 2.68 & 2.72 & 2.69 & 2.75 & 2.71 & 2.82 \\
\hline$\frac{\frac{\text { Liquid Limit \% }}{\text { Plastic Limit \% }}}{\text { Plasticity Index \% }}$ & $\begin{array}{l}24 \\
\text { NP } \\
-\end{array}$ & $\begin{array}{l}25 \\
\text { NP } \\
-\end{array}$ & $\begin{array}{l}26 \\
\text { NP } \\
-\end{array}$ & $\begin{array}{l}36 \\
25 \\
11\end{array}$ & $\begin{array}{l}28 \\
17 \\
11\end{array}$ & $\begin{array}{l}43 \\
26 \\
17\end{array}$ \\
\hline Activity of Clay & - & - & - & 0.578 & 0.423 & 0.68 \\
\hline Linear Shrinkage \% & 1.855 & 4.00 & 3.96 & 6.79 & 5.89 & 8.68 \\
\hline $\begin{array}{l}\frac{\text { Clay } \%}{\text { Silt } \%} \\
\text { Sand \% }\end{array}$ & $\begin{array}{l}12 \\
56 \\
32\end{array}$ & $\begin{array}{l}13 \\
59 \\
28\end{array}$ & $\begin{array}{l}18 \\
56 \\
26\end{array}$ & $\begin{array}{l}19 \\
57 \\
24\end{array}$ & $\begin{array}{l}25 \\
47 \\
28\end{array}$ & $\begin{array}{l}25 \\
56 \\
19\end{array}$ \\
\hline Classification of Soil & ML & ML & ML & CL & CL & CL \\
\hline
\end{tabular}

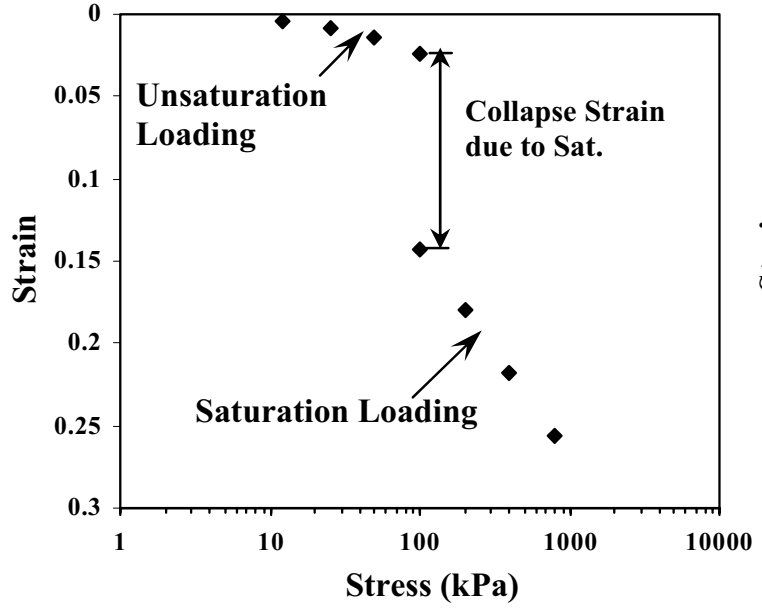

Fig. (3) Collapse Test for Undisturbed Sample

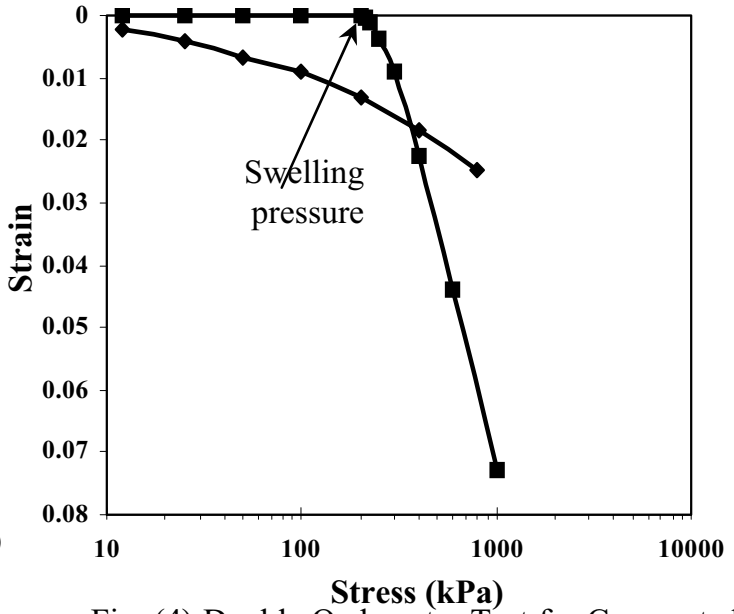

Fig. (4) Double Oedometer Test for Compacted Samples Mixed with $30 \%$ of $(\mathrm{CH})$ Clayey Soil . 


$\begin{array}{llll}\text { Al-Rafidain Engineering } & \text { Vol.15 } & \text { No.4 } & 2007\end{array}$

\section{3-3 Effect of clay addition on volume change of collapsible soil:}

The results of collapse potential for the compacted sample with different percentage of clay additive were presented in Table (4) and Figure (5) (a-d), at different stresses and low dry unit weights $(12.75,14.23) \mathrm{kN} / \mathrm{m}^{3}$. It is observed that, in general, the collapse potential (Cp) increases continuously with increase of (CL\%) soil, while $(\mathrm{Cp})$ reached a maximum value at $(\mathrm{CH})$ soil contents of $(12 \%)$. This observation can be explained by the fact that a portion of the fine-grained soil (clay fraction in this case) acts as a bonding material for large-grain particles. At low water contents, the clay particles at the contacts provide shear strength that resists deformation. The higher clay content, the higher the resistance to densification, (i.e higher void ratio). However, when the soil inundated, the clay binder is partially or fully broken, lubricated and thus facilitating their slipping and sliding against each other [3], [6]. However, this phenomena depends on the type and amount of the clay additive, hence, when a highly plastic clayey soil is used, collapse potential decreases at clay content more than (12\%) as a result of swelling which reduces the void ratio for specimen. Consequently, collapse potential for highly plastic soil is less than that of low plastic soil.

Collapse potential was affected by the applied stresses, the greater the pressure, the greater the collapse, but, collapse was reached highest value at certain pressure where the dry specimen is mixed with (CL) soil with loose structure which breaks down, beyond which the collapse was reduced. However, this behavior depends on the type of the clay additive as the dry specimen with $(\mathrm{CH})$ soil are more stable under applied pressure as shown in Table (4).

Samples prepared at high dry unit weights $(15.69,16.68) \mathrm{kN} / \mathrm{m}^{3},(\mathrm{Cp})$ decreases considerably for compacted soil with and without clay additives, at certain stress. The denser soil has lower initial void ratios, which leads to a lesser collapse upon wetting. In the other hand, the use of increased relative compaction resulted in a significantly increase in swelling of the soil during inundation. The swelling pressure increased with the increase of the amounts of two types of clayey soil. (i.e greater plastic soil, the greater swelling pressure) as shown in Table (2).

The state diagrams that described the correlation between the final water content and volume was presented Fig. (6). These diagrams are affected by many factors namely: initial water content, applied stresses, initial dry unit weight as well as the amount and clay types. It can be noticed that there are gradual decreases in volume with the increase of water content and applied stresses. Compressibility for undisturbed natural soil at low moisture was less than disturbed samples due to bonding force between these particles. But the inverse was obtained at saturation as a result of weakening and breakdown of these bonding agents. The increase of the initial dry unit weight leads to the convergence of the stress paths from each other, and hence, a decrease of compressibility at any certain value of the applied stress and water content was obtained.

The effect of the amount and types of clay on these diagrams were showed in Figures (7-11) and Tables (5 and 6), at any value of dry unit weight, water content 
Khattab : Role Of Clays Addition On The Stability Of Collapsible Soil

Table (4) Collapse Potential of Collapsible Soil and Soil Mixtures

\begin{tabular}{|c|c|c|c|c|c|c|c|c|c|}
\hline \multirow{2}{*}{$\underset{k \mathbf{k} / \mathbf{m}^{3}}{\gamma_{\mathbf{s}}}$} & \multirow{2}{*}{$\begin{array}{l}\text { Stress } \\
(\mathbf{k P a})\end{array}$} & \multicolumn{4}{|c|}{ CL } & \multicolumn{4}{|c|}{$\mathrm{CH}$} \\
\hline & & $0 \%$ & $5 \%$ & $15 \%$ & $30 \%$ & $0 \%$ & $5 \%$ & $15 \%$ & $30 \%$ \\
\hline \multirow{7}{*}{12.75} & 12 & 0.802 & 3.240 & 12.350 & 14.652 & 0.802 & 6.891 & 4.131 & 2.379 \\
\hline & 25 & 1.136 & 6.576 & 14.424 & 17.556 & 1.136 & 8.796 & 6.610 & 4.164 \\
\hline & 50 & 3.396 & 8.027 & 15.192 & 18.720 & 3.396 & 11.204 & 9.913 & 7.700 \\
\hline & 100 & 4.091 & 9.741 & 15.975 & 19.907 & 4.091 & 13.885 & 13.241 & 11.496 \\
\hline & 200 & 3.769 & 11.15 & 14.746 & 20.170 & 3.769 & 13.120 & 15.735 & 15.447 \\
\hline & 400 & $\begin{array}{l}5.815 \\
\end{array}$ & 11.37 & 14.69 & 17.041 & 5.815 & 15.912 & 17.646 & 16.924 \\
\hline & 800 & 0.562 & 10.85 & 11.022 & 14.252 & 0.562 & 15.036 & 16.088 & 16.015 \\
\hline \multirow{7}{*}{14.23} & 12 & 0.438 & 1.442 & 5.269 & 7.1922 & 0.438 & 0.262 & 0.615 & Swell \\
\hline & 25 & 0.494 & 4.148 & 7.777 & 10.655 & 0.494 & 1.014 & 0.448 & Swell \\
\hline & 50 & 0.856 & 5.726 & 8.945 & 12.573 & 0.856 & 3.266 & 1.711 & 1.735 \\
\hline & 100 & 2.513 & 7.737 & 10.266 & 14.838 & 2.513 & 5.777 & 3.619 & 4.5 \\
\hline & 200 & $\begin{array}{l}5.828 \\
\end{array}$ & 10.10 & 12.021 & 17.165 & 5.828 & 8.350 & 7.740 & 10.67 \\
\hline & 400 & 7.860 & 12.50 & 13.629 & 19.405 & 7.860 & 9.750 & 10.073 & \begin{tabular}{|l|}
13.83 \\
\end{tabular} \\
\hline & 800 & 11.22 & 12.72 & 13.184 & 19.089 & 11.22 & 11.634 & 10.447 & 14.01 \\
\hline \multirow{7}{*}{15.69} & 12 & Swell & Swell & Swell & Swell & Swell & Swell & Swell & Swell \\
\hline & 25 & - & Swell & - & - & - & Swell & Swell & Swell \\
\hline & 50 & - & - & 3.132 & 1.721 & - & Swell & Swell & Swell \\
\hline & 100 & - & - & 6.013 & 4.955 & - & - & - & Swell \\
\hline & 200 & 0.079 & 1.180 & 9.022 & 8.113 & 0.079 & 0.227 & 0.835 & - \\
\hline & 400 & 0.880 & 4.280 & 11.717 & 11.005 & $\begin{array}{l}0.88 \\
\end{array}$ & 1.654 & 4.539 & 2.944 \\
\hline & 800 & 3.056 & 7.630 & 13.885 & 13.590 & 3.056 & 3.538 & 7.982 & 6.522 \\
\hline \multirow{7}{*}{16.68} & 12 & Swell & Swell & Swell & Swell & Swell & Swell & Swell & Swell \\
\hline & 25 & Swell & Swell & Swell & Swell & Swell & Swell & Swell & Swell \\
\hline & 50 & - & - & Swell & Swell & - & Swell & Swell & Swell \\
\hline & 100 & - & - & 0.579 & 0.977 & - & - & Swell & Swell \\
\hline & 200 & 0.559 & 0.888 & 3.335 & 3.886 & 0.559 & - & - & Swell \\
\hline & 400 & 0.791 & 3.574 & 5.909 & 6.765 & 0.791 & - & - & 0.425 \\
\hline & 800 & 1.445 & 6.769 & 8.704 & 9.610 & 1.445 & 1.357 & 1.784 & 3.477 \\
\hline
\end{tabular}

and applied stresses. It could be seen that the stress paths diverge from each other with the increase of the amount of clayey soil. This is because clay particles help the coarse grain soil to slide and slips on each other, therefore, the compressibility increased. For the soil mixture with (CL), the volume change was more than that with $(\mathrm{CH})$ soil. This could be attributed to the lesser cation exchange capacity for the natural soil mixed with (CL), which helps to reduce the binder force between particles. 


\begin{tabular}{llll} 
Al-Rafidain Engineering & Vol.15 & No.4 & 2007 \\
\hline
\end{tabular}

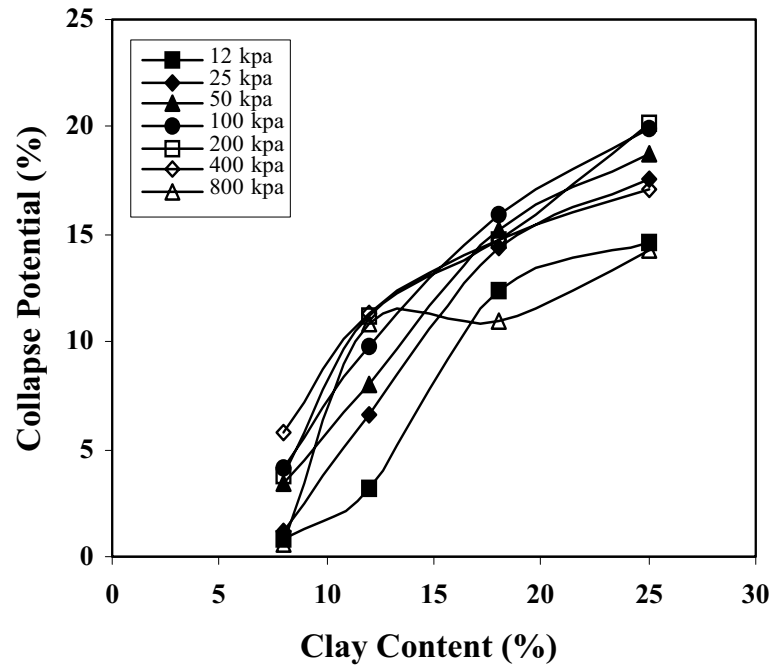

(a) Collapse potential for soil mixed with (CL) Clayey Soil at $\left(\gamma_{\mathrm{d}}=12.75 \mathrm{kN} / \mathrm{m}^{3}\right)$

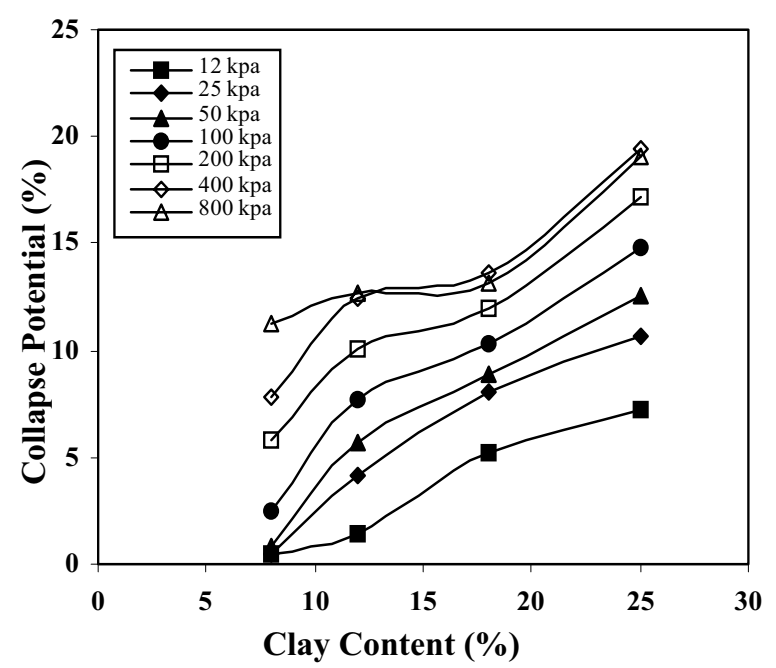

(c) Collapse potential for soil mixed with (CL) Clayey Soil at $\left(\gamma_{\mathrm{d}}=14.23 \mathrm{kN} / \mathrm{m}^{3}\right)$

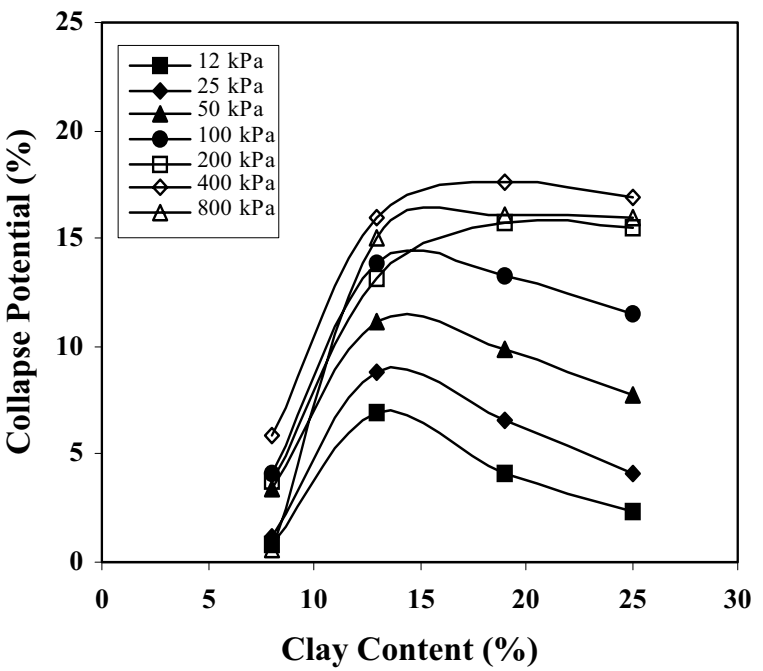

(b) Collapse potential for soil mixed with (CH) Clayey Soil at $\left(\gamma_{\mathrm{d}}=12.75 \mathrm{kN} / \mathrm{m}^{3}\right)$

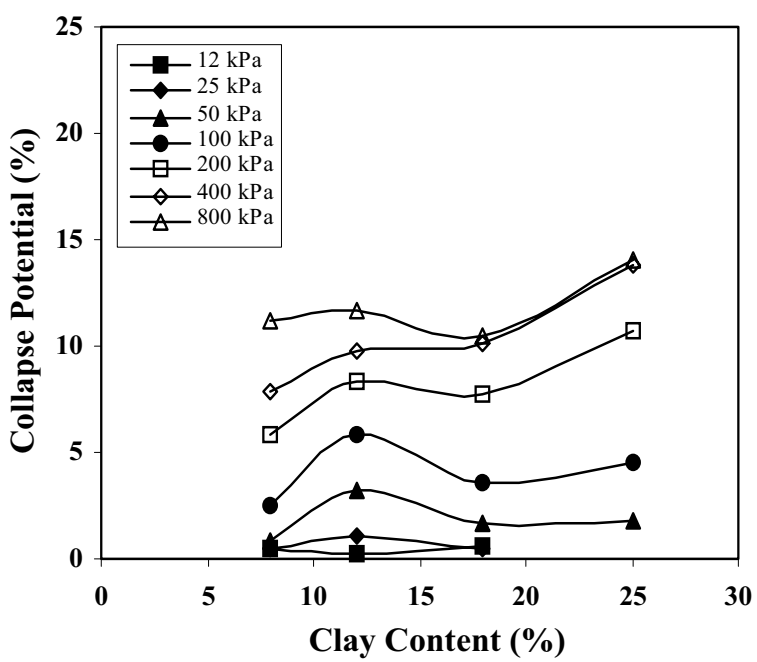

(d) Collapse potential for soil mixed with (CH) Clayey Soil at $\left(\gamma_{\mathrm{d}}=14.23 \mathrm{kN} / \mathrm{m}^{3}\right)$

Fig. (5) Collapse Potential for Compacted Samples Mixed with Two Types of Clayey Soil at Different Unit Weights. 
Khattab : Role Of Clays Addition On The Stability Of Collapsible Soil

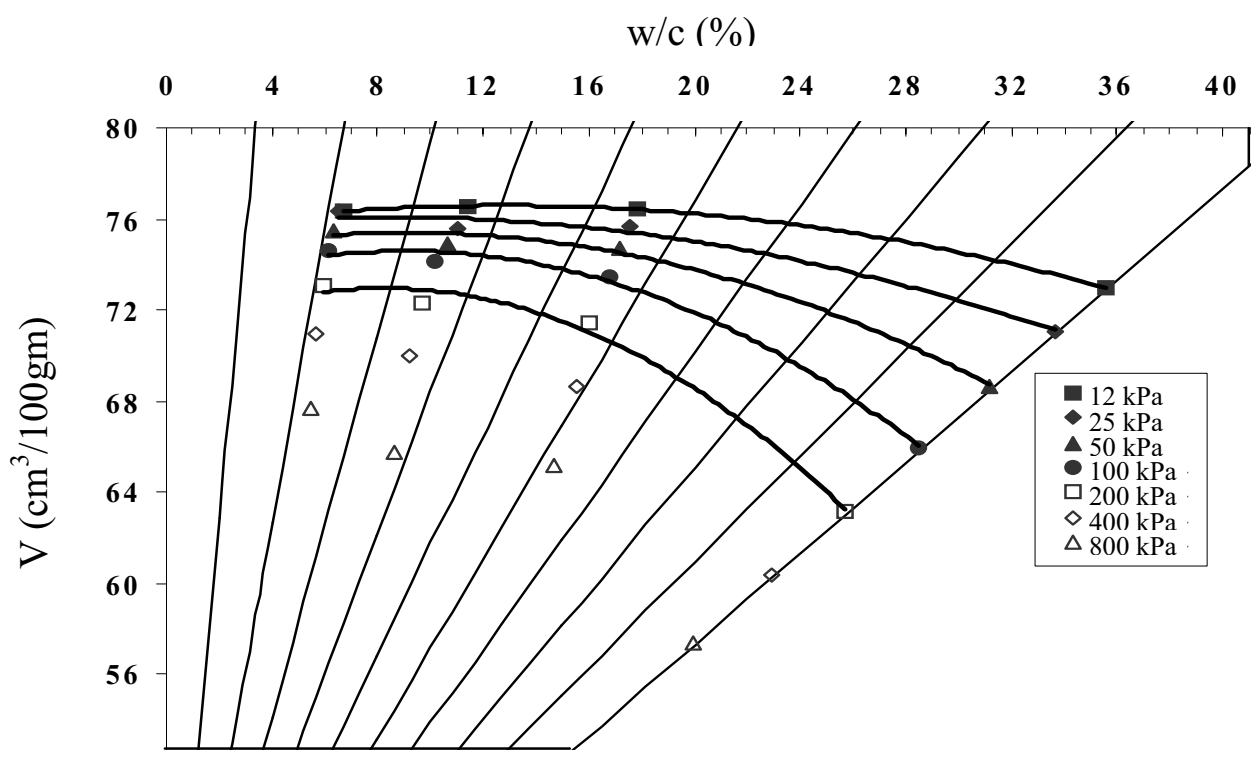

Fig.(6 ) State Diagram for Undisturbed Samples $\mathbf{w} / \mathbf{c}$

$\mathbf{w} / \mathbf{c}$
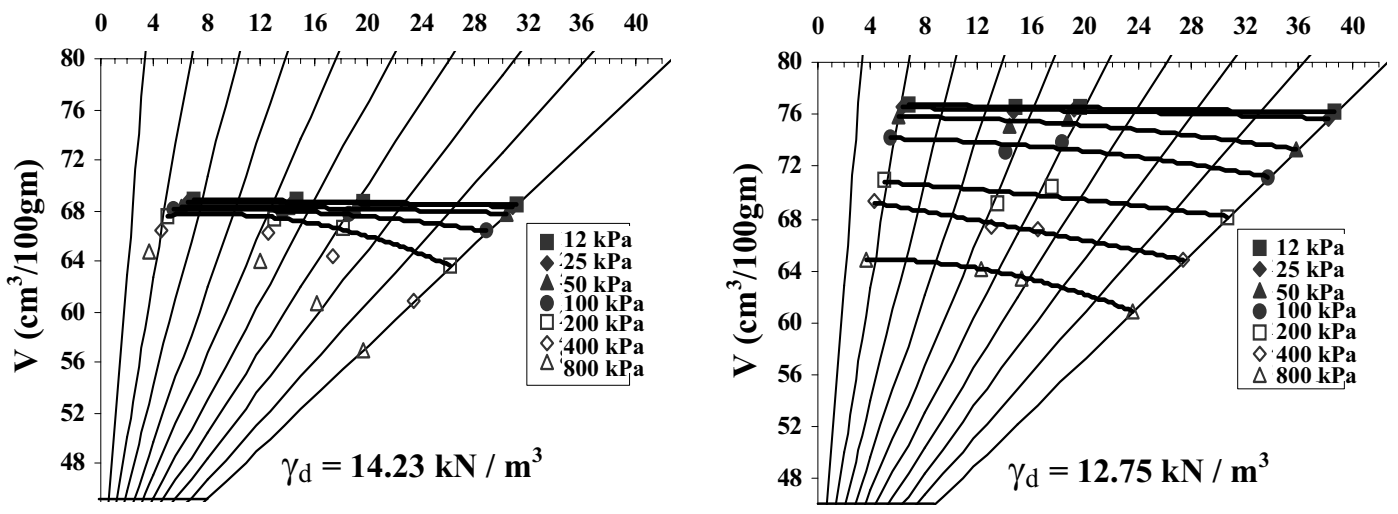

$\mathbf{w} / \mathbf{c}$
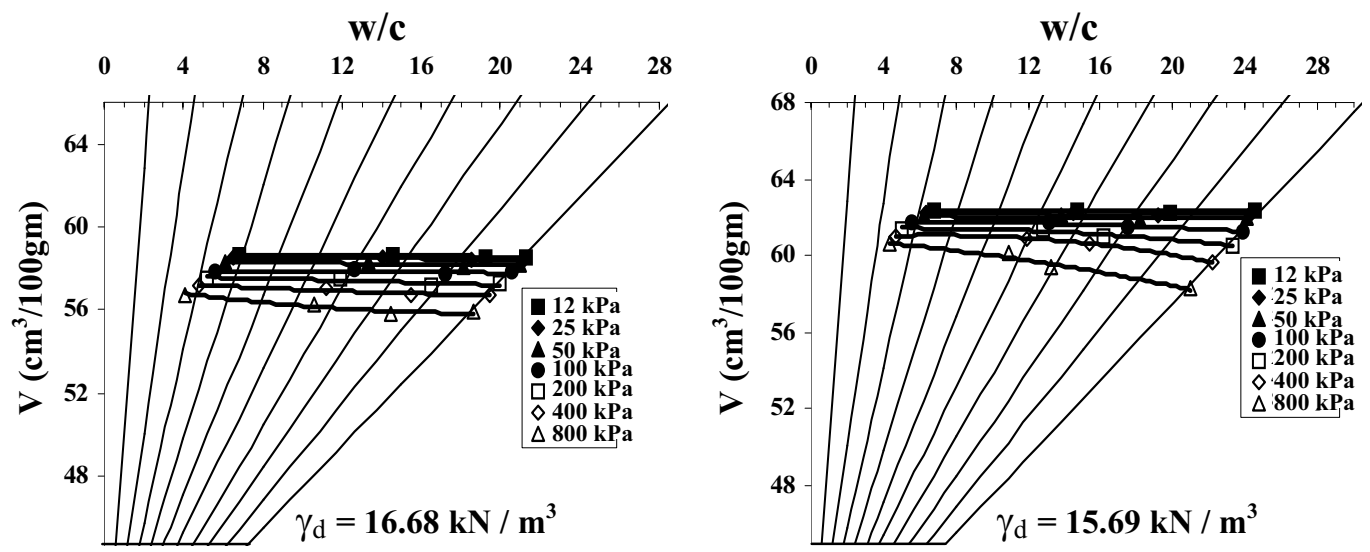

Fig.(7 ) State Diagrams for Disturbed Samples at Different Unit Weights. 


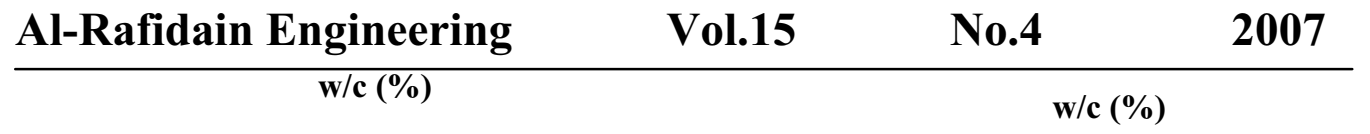

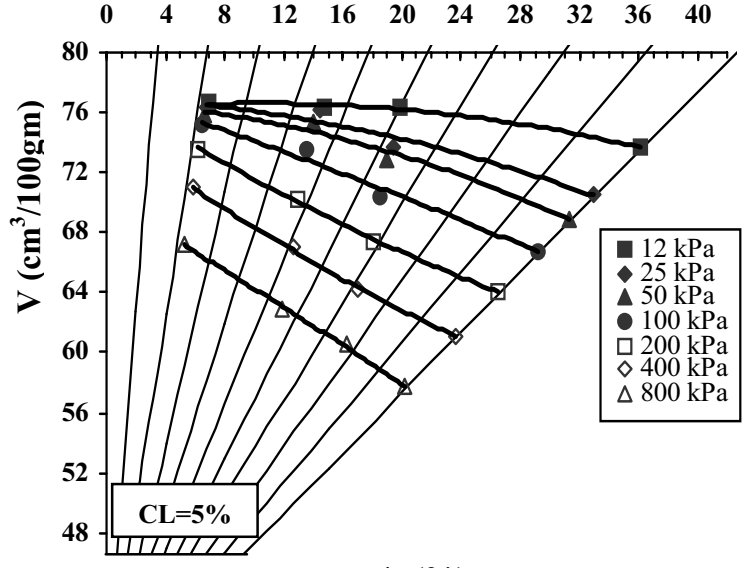

w/c (\%)
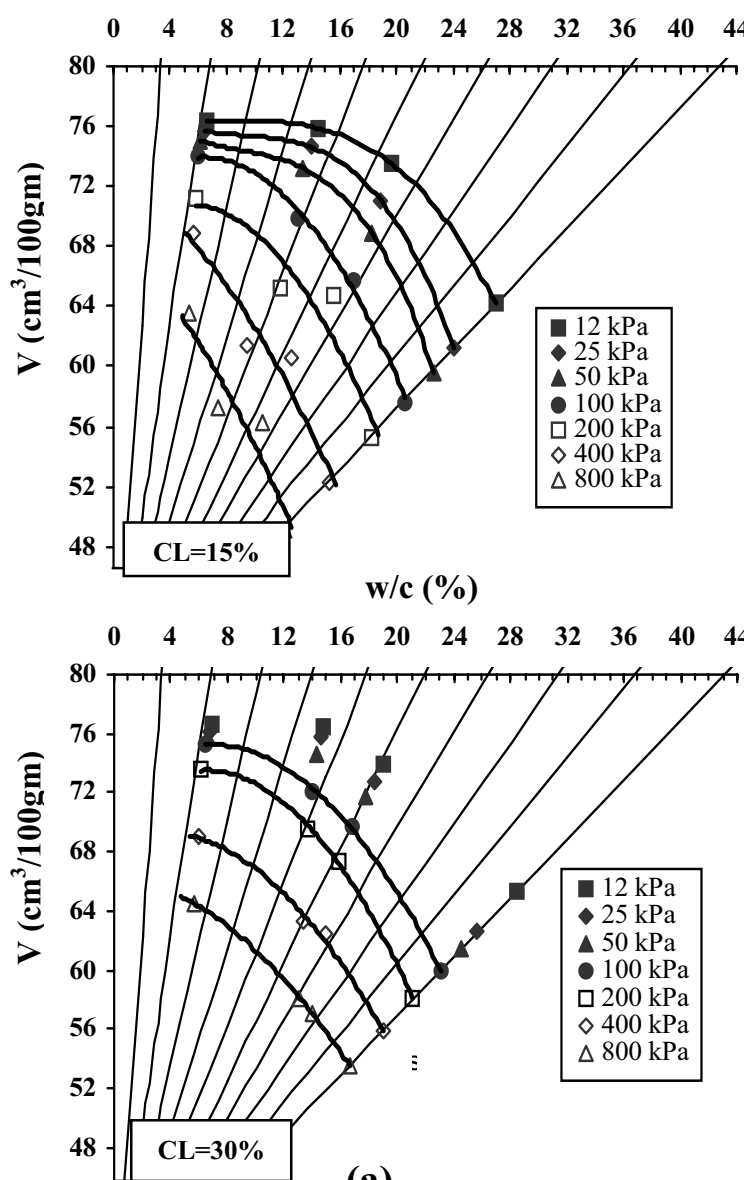

(a)

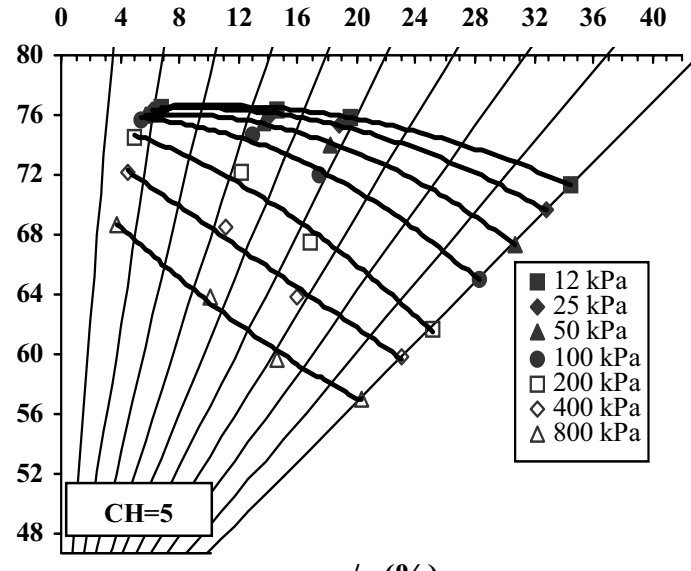

$\mathbf{w} / \mathbf{c}(\%)$

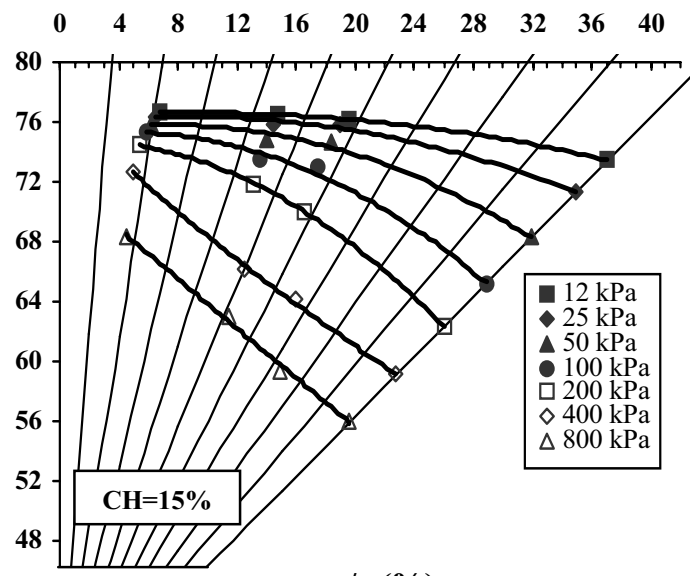

$\mathbf{w} / \mathbf{c}(\%)$

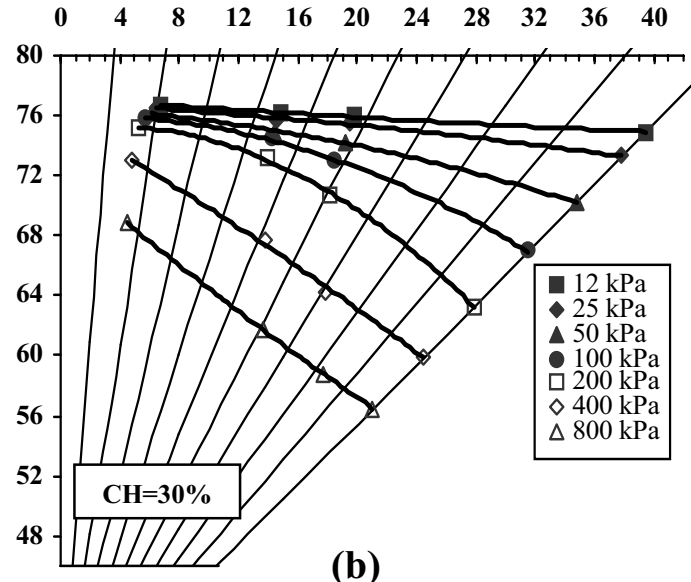

(b)

Fig.(8) state diagrams for disturbed samples at unit weight $\left(\gamma_{d}=12.75 \mathrm{kN} / \mathrm{m}^{3}\right)$

for: a- samples mixed with (CL) clayey soil.

b- samples mixed with $(\mathrm{CH})$ clayey soil. 
Khattab : Role Of Clays Addition On The Stability Of Collapsible Soil

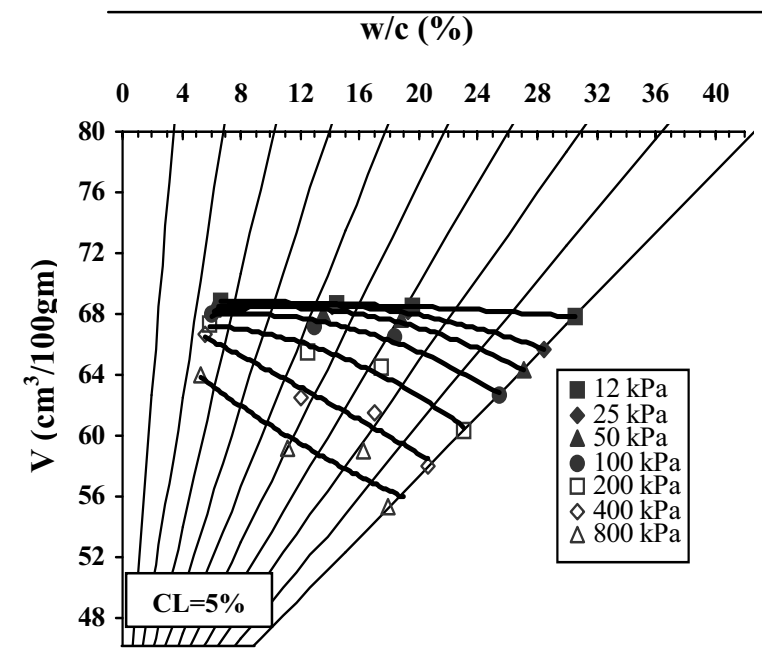

$\mathbf{w} / \mathbf{c}(\%)$

$\mathbf{w} / \mathbf{c}(\%)$

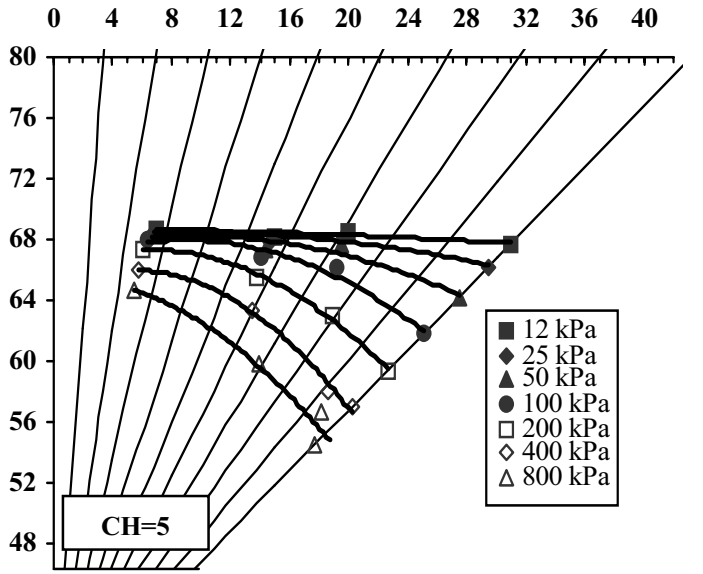

$\mathbf{w} / \mathbf{c}(\%)$
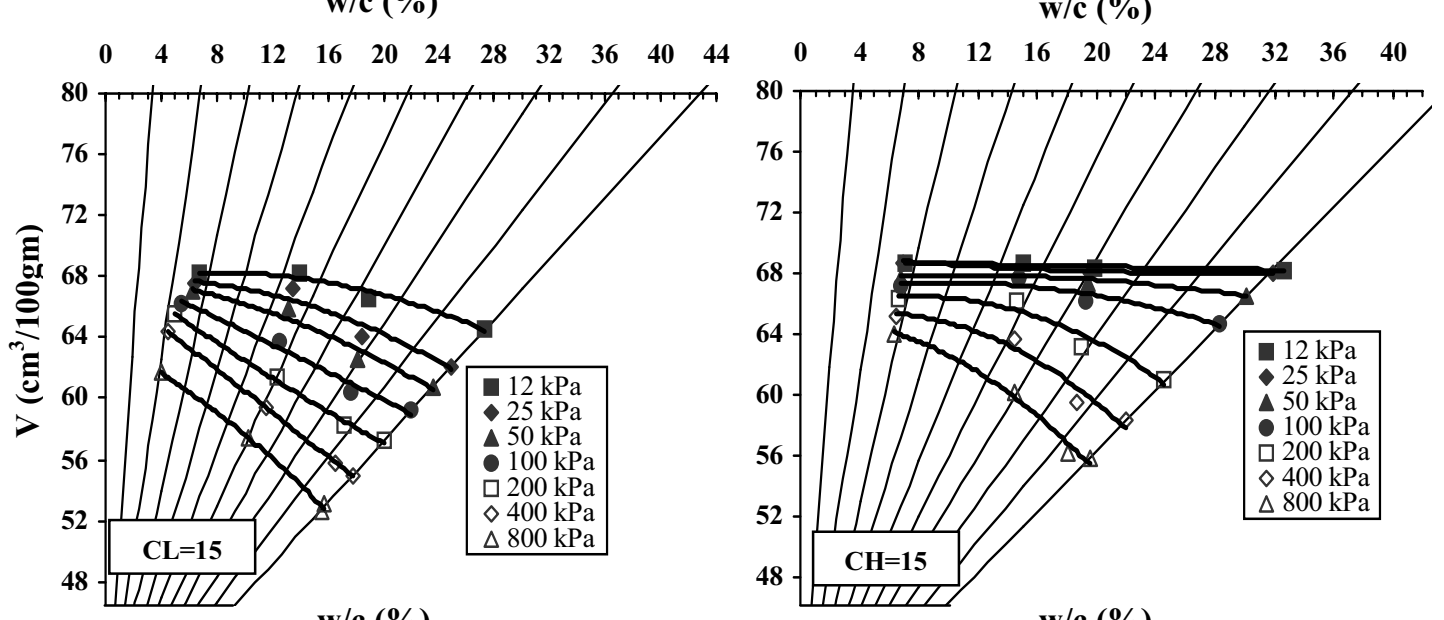

$\mathbf{w} / \mathbf{c}(\%)$

$\mathbf{w} / \mathbf{c}(\%)$
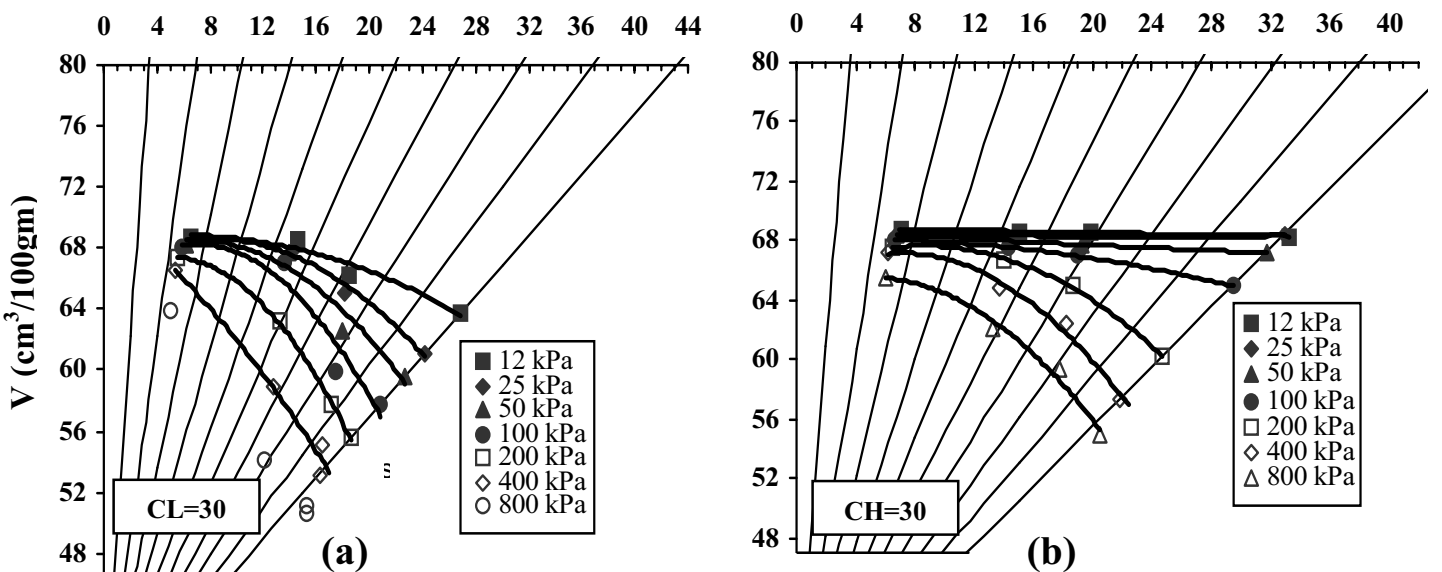

Fig.(9) state diagrams for disturbed samples at unit weight $\left(\gamma_{d}=14.23 \mathrm{kN} / \mathrm{m}^{3}\right)$

for: a- Samples mixed with (CL) clayey soil.

b- Samples mixed with $(\mathrm{CH})$ clayey soil. 


\begin{tabular}{cccc} 
Al-Rafidain Engineering & Vol.15 & No.4 & 2007 \\
\hline w/c (\%) & & w/c (\%)
\end{tabular}

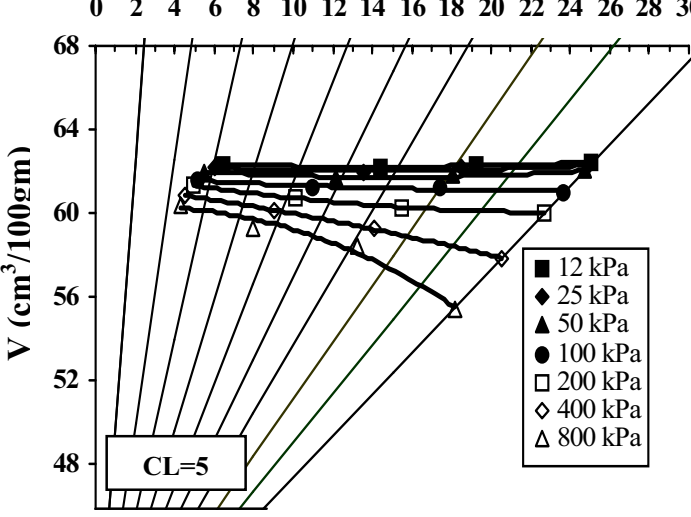

w/c (\%)

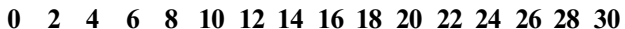

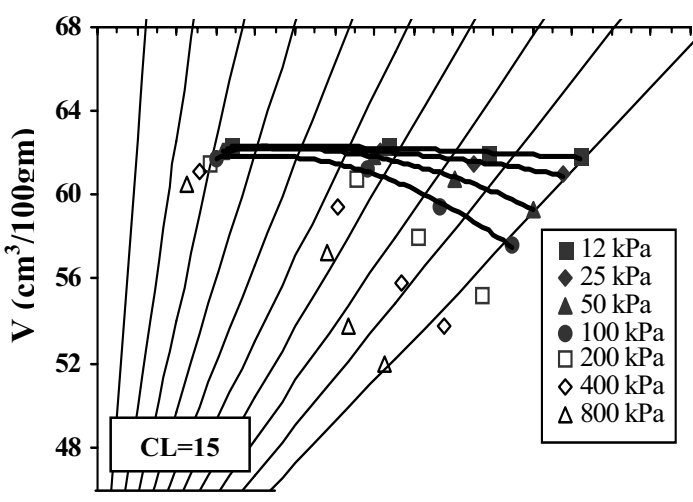

w/c (\%)

$\begin{array}{llllllllllllllll}0 & 2 & 4 & 6 & 8 & 10 & 12 & 14 & 16 & 18 & 20 & 22 & 24 & 26 & 28 & 30\end{array}$

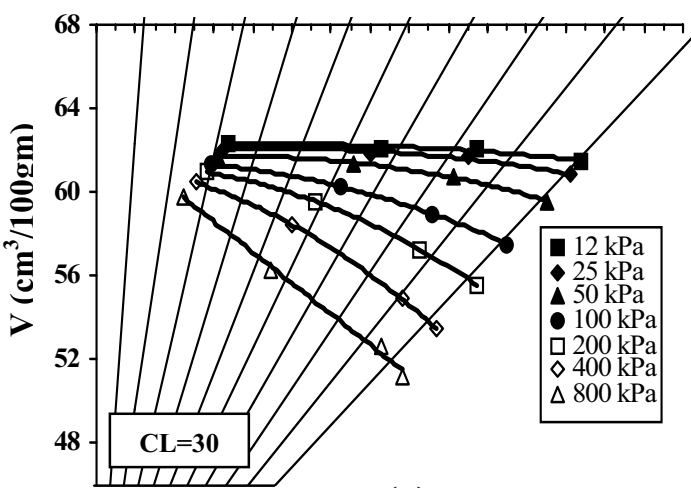

(a)

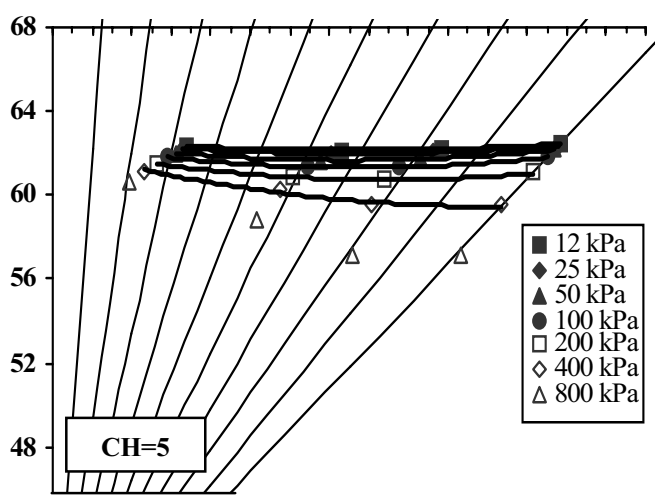

w/c (\%)

$\begin{array}{llllllllllllllll}0 & 2 & 4 & 6 & 8 & 10 & 12 & 14 & 16 & 18 & 20 & 22 & 24 & 26 & 28 & 30\end{array}$

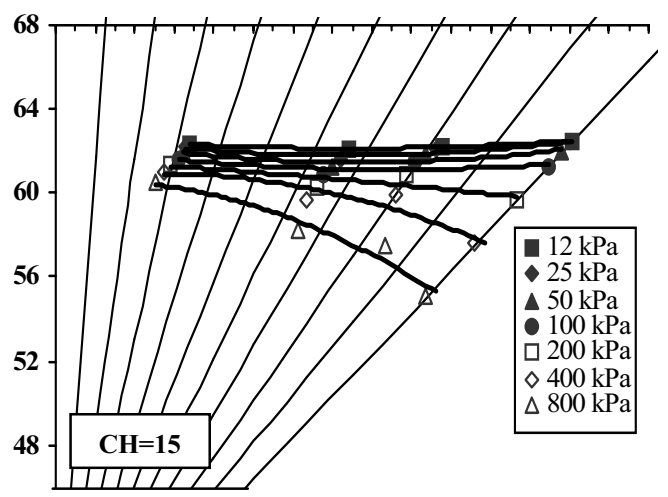

w/c (\%)

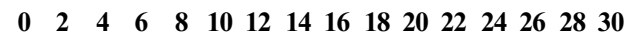

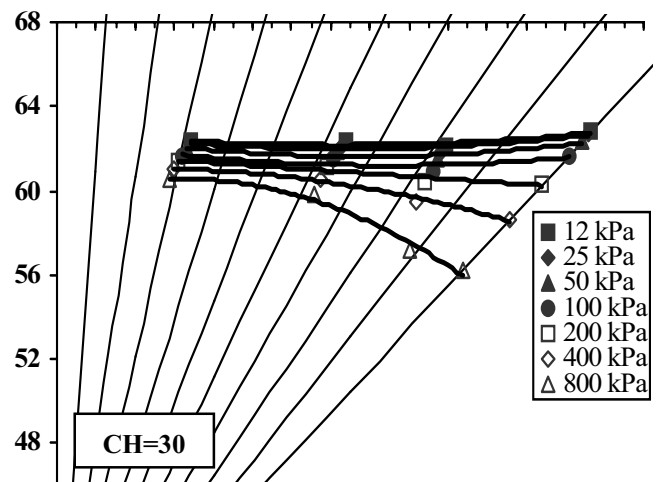

(b)

Fig.(10) state diagrams for disturbed samples at unit weight $\left(\gamma_{d}=15.69 \mathrm{kN} / \mathrm{m}^{3}\right)$ for:

(a) Samples mixed with (CL) clayey soil.

(b) Samples mixed with $(\mathrm{CH})$ clayey soil. 
Khattab : Role Of Clays Addition On The Stability Of Collapsible Soil

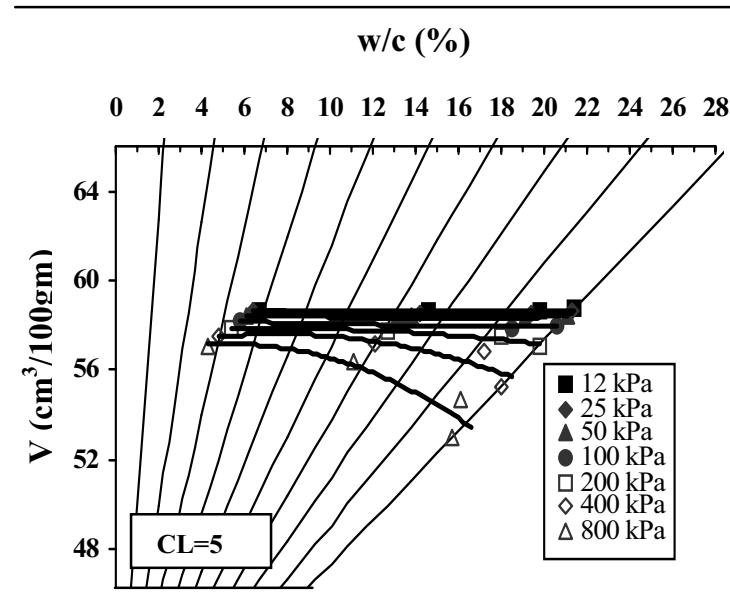
w/c (\%)

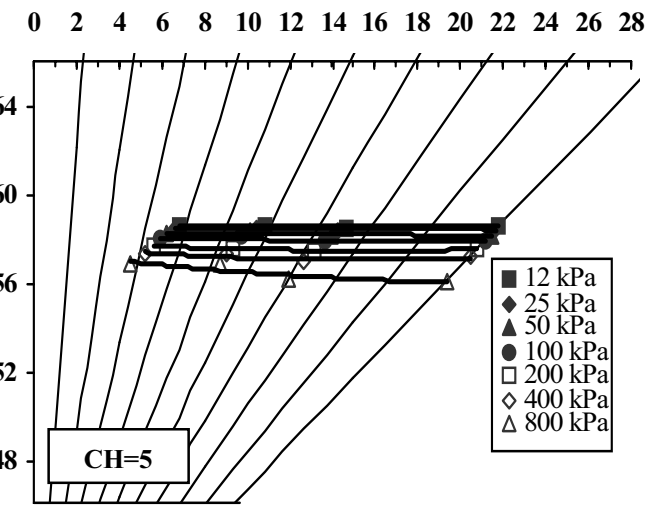

$\mathbf{w} / \mathbf{c}(\%)$

$\mathbf{w} / \mathbf{c}(\%)$

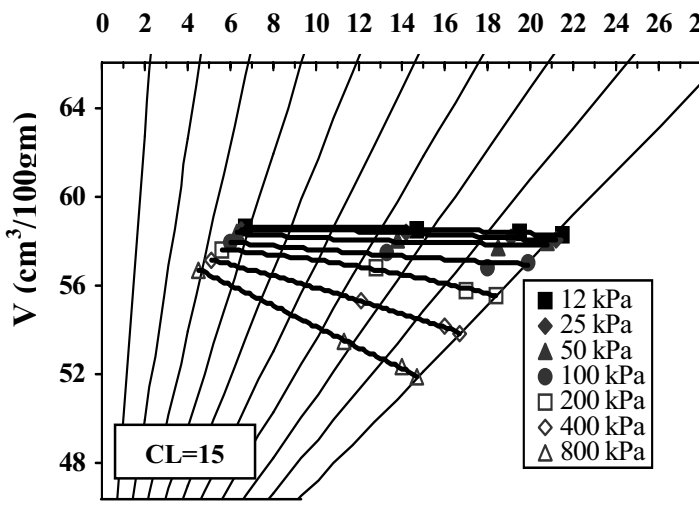

$\mathbf{w} / \mathbf{c}(\%)$

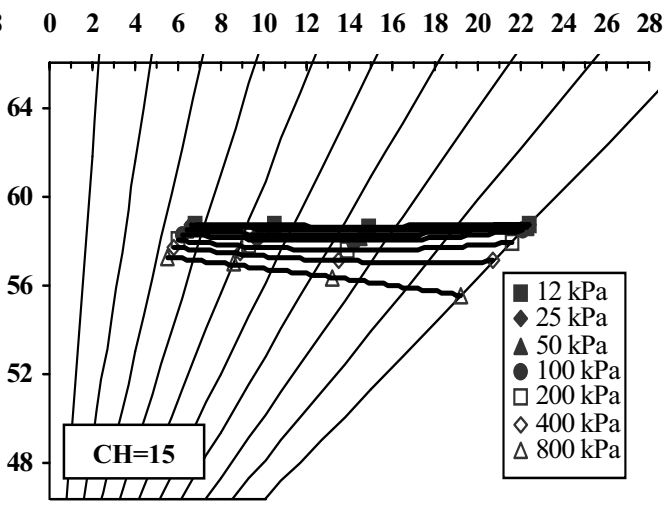

$\mathbf{w} / \mathbf{c}(\%)$

$\begin{array}{llllllllllllllllllllllllllllll}0 & 2 & 4 & 6 & 8 & 10 & 12 & 14 & 16 & 18 & 20 & 22 & 24 & 26 & 28 & 0 & 2 & 4 & 6 & 8 & 10 & 12 & 14 & 16 & 18 & 20 & 22 & 24 & 26 & 28\end{array}$
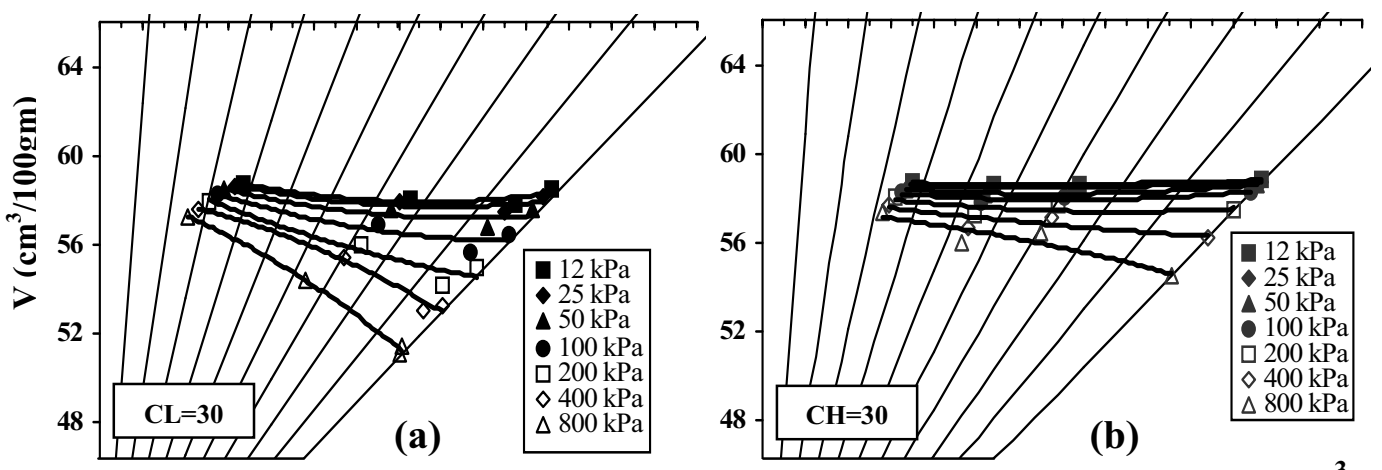

Fig.(11) state diagrams for disturbed samples at unit weight $\left(\gamma_{d}=16.68 \mathrm{kN} / \mathrm{m}^{3}\right)$

for: a- Samples mixed with (CL) clayey soil.
b-
Samples
mixed
with
(CH) clayey soil. 
Table (5) Volume Change (\%) of Collapsible Soil Mixed with Tow Types of Clayey Soil Under Different Unit Weights with Applied Stress of (400 kPa).

\begin{tabular}{|c|c|c|c|c|c|c|c|c|c|c|}
\hline \multirow{2}{*}{$\underset{k \mathbf{k} / \mathbf{m}^{3}}{\gamma_{\mathbf{3}}}$} & \multirow{2}{*}{$\begin{array}{c}\% \\
\text { Adding }\end{array}$} & \multirow{2}{*}{$\begin{array}{c}\% \\
\text { Clay }\end{array}$} & \multicolumn{3}{|c|}{$\%$ w/c } & \multirow{2}{*}{$\begin{array}{c}\% \\
\text { Adding }\end{array}$} & \multirow{2}{*}{$\begin{array}{c}\% \\
\text { Clay }\end{array}$} & \multicolumn{3}{|c|}{$\%$ w/c } \\
\hline & & & $7-10$ & $7-15$ & 7-sat. & & & $7-10$ & $7-15$ & 7-sat. \\
\hline \multirow{4}{*}{12.75} & $\mathrm{CL}=0$ & 8 & 0.69 & 1.91 & 5.105 & $\mathrm{CH}=0$ & 8 & 0.698 & 1.903 & 5.105 \\
\hline & $C L=5$ & 12 & 2.77 & 7.39 & 15.33 & $\mathrm{CH}=5$ & 13 & 2.667 & 7.076 & 14.14 \\
\hline & $C L=15$ & 18 & 5.36 & 17.0 & 17.54 & $\mathrm{CH}=15$ & 19 & 3.221 & 8.241 & 15.19 \\
\hline & $\mathbf{C L}=\mathbf{3 0}$ & 25 & 2.52 & 9.08 & 16.39 & $\mathbf{C H}=\mathbf{3 0}$ & 25 & 2.429 & 6.679 & 15.44 \\
\hline \multirow{4}{*}{14.23} & $\mathrm{CL}=0$ & 8 & 0.14 & 1.58 & 7.44 & $\mathrm{CH}=0$ & 8 & 0.144 & 1.579 & 7.44 \\
\hline & $C L=5$ & 12 & 2.21 & 6.02 & 10.57 & $\mathrm{CH}=5$ & 13 & 0.516 & 3.980 & 10.24 \\
\hline & $C L=15$ & 18 & 5.97 & 11.8 & 14.14 & $\mathrm{CH}=15$ & 19 & 0.895 & 3.74 & 10.92 \\
\hline & $\mathrm{CL}=\mathbf{3 0}$ & 25 & 4.48 & 13.1 & 15.55 & $\mathbf{C H}=\mathbf{3 0}$ & 25 & 0.718 & 3.931 & 13.84 \\
\hline \multirow{4}{*}{15.69} & $\mathrm{CL}=0$ & 8 & 0.10 & 0.66 & 2.337 & $\mathrm{CH}=0$ & 8 & 0.096 & 0.654 & 2.337 \\
\hline & $C L=5$ & 12 & 1.74 & 3.24 & 5.118 & $\mathrm{CH}=5$ & 13 & 0.726 & 1.589 & 2.075 \\
\hline & $C L=15$ & 18 & 2.34 & 7.31 & 12.37 & $\mathrm{CH}=15$ & 19 & 0.792 & 1.806 & 4.880 \\
\hline & $\mathrm{CL}=\mathbf{3 0}$ & 25 & 3.18 & 5.06 & 7.722 & $\mathrm{CH}=30$ & 25 & 0.886 & 1.827 & 4.545 \\
\hline \multirow{4}{*}{16.68} & $\mathrm{CL}=0$ & 8 & 0.08 & 0.53 & 0.741 & $\mathrm{CH}=0$ & 8 & 0.073 & 0.529 & 0.741 \\
\hline & $C L=5$ & 12 & 0.16 & 1.50 & 2.951 & $\mathrm{CH}=5$ & 13 & 0.232 & 0.374 & 0.181 \\
\hline & $C L=15$ & 18 & 0.93 & 5.56 & 6.474 & $\mathrm{CH}=15$ & 19 & 0.470 & 0.894 & 0.826 \\
\hline & $\mathrm{CL}=\mathbf{3 0}$ & 25 & 1.78 & 5.76 & 6.729 & $\mathbf{C H}=\mathbf{3 0}$ & 25 & 0.534 & 1.305 & 2.194 \\
\hline
\end{tabular}

Table (6) Volume Change (\%) of Collapsible Soil Mixed with Tow Types of Clayey Soil Under Different Unit Weights with water contents (15\%).

\begin{tabular}{|c|c|c|c|c|c|c|c|c|c|c|}
\hline \multirow{2}{*}{$\underset{\mathbf{k N} / \mathbf{m}^{3}}{\gamma_{\mathbf{d}}}$} & \multirow{2}{*}{$\begin{array}{c}\% \\
\text { Adding }\end{array}$} & \multicolumn{4}{|c|}{ Stress (kPa) } & \multirow{2}{*}{$\begin{array}{c}\% \\
\text { Adding }\end{array}$} & \multicolumn{4}{|c|}{ Stress (kPa) } \\
\hline & & 100 & 200 & 400 & 800 & & 100 & 200 & 400 & 800 \\
\hline \multirow{4}{*}{12.75} & $\mathrm{CL}=0$ & 4.24 & 9.06 & 12.3 & 17.4 & $\mathrm{CH}=0$ & 4.24 & 9.06 & 12.3 & 17.3 \\
\hline & $\mathrm{CL}=5$ & 6.03 & 10.3 & 16.4 & 20.5 & $\mathrm{CH}=5$ & 4.53 & 9.50 & 15.3 & 22.1 \\
\hline & $C L=15$ & 11.6 & 18.5 & 30.3 & 43.2 & $\mathrm{CH}=15$ & 4.50 & 7.80 & 16.1 & 22.3 \\
\hline & $\mathrm{CL}=30$ & 7.40 & 11.6 & 20.1 & 27.5 & $\mathrm{CH}=\mathbf{3 0}$ & 3.63 & 4.77 & 13.4 & 21.0 \\
\hline \multirow{4}{*}{14.23} & $\mathrm{CL}=0$ & 1.50 & 2.65 & 5.17 & 10.2 & $\mathrm{CH}=0$ & 1.50 & 2.65 & 5.17 & 10.1 \\
\hline & $\mathrm{CL}=5$ & 2.62 & 5.63 & 10.7 & 16.2 & $\mathrm{CH}=5$ & 2.7 & 5.55 & 9.99 & 15.3 \\
\hline & $C L=15$ & 9.83 & 13.5 & 17.5 & 17.8 & $\mathrm{CH}=15$ & 2.60 & 5.14 & 8.99 & 13.8 \\
\hline & $\mathrm{CL}=30$ & 6.47 & 11.6 & 18.8 & 25.8 & $\mathrm{CH}=\mathbf{3 0}$ & 2.15 & 3.59 & 6.59 & 11.1 \\
\hline \multirow{4}{*}{15.69} & $\mathrm{CL}=0$ & 1.41 & 2.13 & 2.97 & 5.18 & $\mathrm{CH}=0$ & 1.41 & 2.13 & 2.97 & 5.18 \\
\hline & $\mathrm{CL}=5$ & 2.10 & 3.86 & 5.57 & 8.35 & $\mathrm{CH}=5$ & 1.90 & 2.79 & 4.37 & 7.93 \\
\hline & $C L=15$ & 2.97 & 5.16 & 9.30 & 13.5 & $\mathrm{CH}=15$ & 2.17 & 3.04 & 4.38 & 7.94 \\
\hline & $\mathrm{CL}=30$ & 4.62 & 7.20 & 11.4 & 16.9 & $\mathbf{C H}=\mathbf{3 0}$ & 2.2 & 3.22 & 4.56 & 8.29 \\
\hline \multirow{4}{*}{16.68} & $\mathrm{CL}=0$ & 1.28 & 1.43 & 2.67 & 4.92 & $\mathrm{CH}=0$ & 1.3 & 1.43 & 2.67 & 4.92 \\
\hline & $\mathrm{CL}=5$ & 1.43 & 2.00 & 3.58 & 7.48 & $\mathrm{CH}=5$ & 1.5 & 2.25 & 2.94 & 4.41 \\
\hline & $C L=15$ & 2.67 & 4.27 & 7.49 & 11.9 & $\mathrm{CH}=15$ & 1.5 & 2.13 & 3.00 & 4.64 \\
\hline & $\mathrm{CL}=30$ & 4.09 & 7.33 & 8.87 & 13.9 & $\mathrm{CH}=\mathbf{3 0}$ & 1.5 & 2.39 & 3.64 & 5.52 \\
\hline
\end{tabular}


Khattab : Role Of Clays Addition On The Stability Of Collapsible Soil

\section{4-Conclusion}

1-Collapse potential increased continuously for samples compacted at a low unit weight, mixed with the percentages of (CL), while there was a maximum collapse potential occurred at a $5 \%$ of $(\mathrm{CH})$ soil.

2-Generally, collapse potential increased with applied stresses using the two clay additives with all placement conditions with the exception of samples compacted at a low unit weight. In this case, where collapse potential reaches a highest value at a certain stress.

3-Collapse potential of soils containing $(\mathrm{CH})$ clays was less than that mixed with (CL) soil.

4-Compressibility for undisturbed natural soil at low moisture content was less than that of disturbed samples, but the inverse was obtained at saturation.

5-Compressibility increases with the increase of the clay additives, where the reduction in volume for soil mixed with (CL) was more than that mixed with $(\mathrm{CH})$.

\section{5-References}

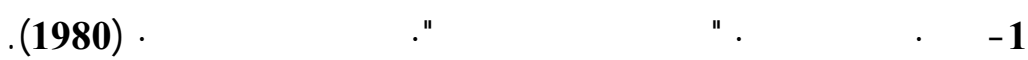

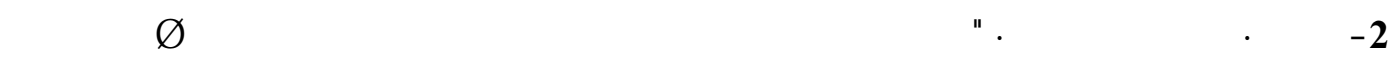

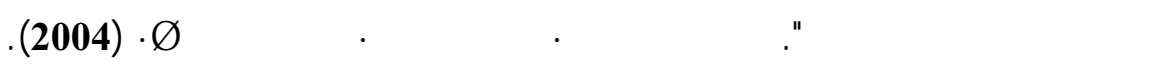

3-Al-Khashab, M.N., and Bahhe, S.W., "The Effect of Particales Fineness on the Stability of Collapsible Soils", Al-Rafidain Engineering Journal, Vol. 7, No. 1, 1999, pp.68-82.

4-ASTM (D 5333-92), "Standards Test Method for Measurement of Collapse Potential of Soils", Annual Book of ASTM Standards, Vol. 04.08, 2003, pp.230232.

5-Barden, L., McGown, A., and Collins, k., "The Collapse Mechanism in Partialy Saturated Soil” Engineering Geology, Amsterdam. 7, 1973, 49 - 60.

6-Basma, A.A., and Tuncer, R.E., "Evaluation and Control of Collapsible Soil," Journal of Geotechnical Engineering, Vol. 118, No. 10, 1992, pp.1491-1504.

7-Clemence. S.P. and Finbarr. A.O. "Design Considerations for Collapsible Soils", Journal of the Geotechnical Engineering Division. ASCE. 107: GT3, 1981, 305317

8-Dalaly, Nael K.,"Probability and Evaluation of Soil Collapsibility", Journal of Engineering and Development, Vol. 8, No. 2, 2004, Pp.71-87 


$\begin{array}{llll}\text { Al-Rafidain Engineering } & \text { Vol.15 } & \text { No.4 } & 2007\end{array}$

9-Dudley, J.H. (1970), "Review of Collapsing Soils", Journal of the Soil Mechanics and Foundations Division. Proceedings of the American Society of Civil Engineers, Vol. 96, No. SM3, 1970, pp. 925 - 947.

10-Gibbs H.J, and Bara J.P, “ Predicting Surface Subsidence from Basic Soil Test” Special Technical Publication, ASTM, No.322, 1962, pp. 231-247.

11-Jennings J.E, and Knight k, "Aguide to Contruction on or with Materials Exhibiting Additional Settlement Due to Collapse of Grains Structure", $6^{\text {th }}$ Reg. Conf. For Africa on Soil Mech. and F. Eng. 1975, pp. 99-105.

12-Jennings J.E. and Knight. K. "The Additional Settlement of Foundations due to Collapse of Structure of Sandy Subsoils on Wetting", proceedings of $4^{\text {th }}$ International Conference on Soil Mechanics and Foundation Engineering. London, Vol. 1, 1957, pp. 316-319.

13-Lawton, E.C., Fragaszy, R.J., and Hardcastle, J.H.,"Collapse of Compacted Clayey Sand”, Geotech. Engrg., ASCE, Vol. 115, No. 9, 1989, pp. 1252-1267.

14-Lawton, E.C., Fragaszy, R.J., and Hetherington, M.D., "Review of WettingInduced Collapse in Compacted Soil", Journal of Geot. Eng. Vol. 118, No. 9. 1992, pp.1376-1394.

15-Mitchell, J.k.,"Foundamentals of Soil Behavior" Wiley. New York, (1976).

16-Rollins, K.M., Smith, T. and Gearge H., "Identification and Characterization of Collapsible Gravels", Journal of Geotechnical Engineering, ASCE,. Vol. 120, No. 1. 1994, pp. 528-542.

17-Silvan, A., Corneliu, A., and Sanda, M.,['Study of Collapsible Soil Properties”, Sixth Danube, European Conference on Soil Mechanics and Foundation Engineering, Civil Engineering Institute Bdul Lacul Tei 124 Bucharest 72302, 1981, pp. 7-22.

18-Sun, D.A., Matsuoka, H. and Xu, Y.F. "Collapse Behavior of Compacted Clays in Suction-Controlled Triaxial Tests", Geotechnical Testing Journal, Vol. 27, No. 4, 2004, pp. 1-9.

The work was carried out at the college of Engg. University of Mosul 